\author{
JACEK M. WiTKOWSKI ${ }^{1}$, EWA BRYL ${ }^{2}$ \\ ${ }^{1}$ Katedra i Zakład Fizjopatologii \\ ${ }^{2}$ Zakład Patologii i Reumatologii Doświadczalnej \\ Gdański Uniwersytet Medyczny \\ Dębinki 7, 80-211 Gdańsk \\ E-mail: jacek.witkowski@gumed.edu.pl
}

\title{
MECHANIZMY COVID-19 A UKŁAD ODPORNOŚCIOWY I JEGO STARZENIE
}

\section{WPROWADZENIE}

Pierwszy przypadek nowej choroby zakaźnej nazwanej choroba koronawirusowa z 2019 r., czyli COVID-19 rozpoznano w Polsce 4 marca 2020 r. Jak wiemy, choroba pojawiła się najprawdopodobniej już w ostatnim kwartale 2019 r. w Chinach, jako odzwierzęca choroba wywołana przez koronawirusa (ostatecznie nazwanego SARS-CoV-2) mającego cechy (genetyczne i inne) bardzo zbliżone do dwóch innych koronawirusów, które zaatakowały w latach 2003 i 2012 (odpowiednio SARS-CoV-1 i MERS-CoV). Wspólnym mianownikiem w patologii infekcji tymi trzema wirusami było szybkie zajęcie płuc i wywołanie masywnej, ostrej niewydolności oddechowej (ang. severe acute respiratory syndrome, SARS; middle east respiratory syndrome, MERS), wymagajacej nie tylko podawania tlenu, ale także wspomagania oddychania za pomoca respiratora, a w najcięższych przypadkach użycia aparatu natleniajaccego krew pozaustrojowo (ang. extracorporeal membrane oxygenator, ECMO).

Ze względu na szybkość rozprzestrzeniania się SARS-CoV-2 na całym świecie i gwałtowny wzrost nie tylko potwierdzonych przypadków osób zainfekowanych (wg danych CDC i ECDC na dzień 6 września 2021 r. w Polsce było ich 2.889.773, a na świecie 222081350), ale także liczby zgonów $\mathrm{w}$ związku $\mathrm{z}$ tą infekcją (odpowiednio
75392 i 4573243 osoby), otrzymała ona wkrótce status pandemii. Doprowadziło to m.in. do zwiększenia wysiłku badaczy w celu zrozumienia mechanizmów COVID-19, a następnie jej zapobiegania i leczenia. Dotychczas, zgodnie $\mathrm{z}$ informacja zawarta w bazie NIH NLM PubMed, opublikowano 174,959 prac naukowych dotyczacych COVID-19 (wrzesień 2021). Skutkiem tych bardzo intensywnych badań jest nie tylko coraz lepsze rozumienie patomechanizmów interakcji SARS-COV-2 z ludzkimi komórkami, ale także powstanie, a następnie wdrożenie naukowych pomysłów opanowania pandemii. Obecnie (wrzesień 2021) mamy już kilka bardzo skutecznych szczepionek przeciwko SARS-COV-2 [powstałych $\mathrm{w}$ oparciu zarówno o tradycyjne, jak i nowoczesne (mRNA) technologie]. Stopniowo wdrażane sa kolejne szczepionki, badane sa także potencjalne leki, m.in. majace albo utrudnić infekcję, albo przeciwdziałać replikacji wirusa w komórkach.

$Z$ podanych powyżej liczb wynika, że COVID-19 nie powoduje tylu zgonów, co osławiona grypa hiszpańska; ocenia się, że $\mathrm{w}$ pandemii tej choroby w 1918 r. zmarło od 20 do nawet 100 milionów osób na całym świecie. Istotne sa jednak także odległe skutki przebytej infekcji SARS-COV-2, które moga prawdopodobnie rzutować na stan zdrowia pacjenta przez wiele lat, a być może do końca życia.

Słowa kluczowe: burza cytokinowa, COVID-19, immunosenescencja, inflammaging, odporność nabyta, odporność wrodzona, starzenie układu odpornościowego 
CZYM JEST COVID-19 Z PUNKTU WIDZENIA IMMUNOLOGA?

Jak wykazano, SARS-CoV-2 rzadko uszkadza lub zabija in vivo zainfekowane komórki w wyniku wewnątrzkomórkowej replikacji, co jest możliwe $\mathrm{w}$ niektórych liniach komórkowych, np. VERO E6, in vitro $\mathrm{i}$ stosowane $\mathrm{w}$ teście oceniajacym potencjalne efekty terapeutyczne różnych związków $\mathrm{w}$ stosunku do wirusa (RAGAN i współaut. 2020). Jednak w trakcie produkcji białek wirusowych w takiej komórce dochodzi do ich przechwycenia przez białka zgodności tkankowej (ang. human leukocyte antigens, HLA) klasy I i umieszczenia fragmentów wirusowych białek na powierzchni zainfekowanych komórek. Tu wirusowe epitopy moga być rozpoznane przez komórki odporności nabytej - cytotoksyczne limfocyty $\mathrm{T}$ klasy CD8+, a także przez należące do komórek odporności wrodzonej komórki naturalnie cytotoksyczne (ang. natural killers, NK). Podstawowa rola tych ostatnich jest bycie "siła szybkiego reagowania" niszczaca zmienione (przez wirusowa infekcje lub nowotworowa transformację) własne komórki organizmu. Jest to możliwe, gdyż komórki NK posiadaja na powierzchni aktywujace receptory, wiażace się $z$ HLA klasy I $z$ osadzonymi obcymi epitopami (BAO i współaut. 2021). Podobnie działaja cytotoksyczne limfocyty $\mathrm{CD} 8+$, ale ich reakcja na zainfekowane komórki jest nieco opóźniona $\mathrm{w}$ stosunku do reakcji komórek NK, gdyż ich kontakt $z$ zainfekowana komórka przed wymierzeniem jej coup-de-grace wymaga pośrednictwa przeciwciała skierowanego przeciwko epitopowi pochodzacemu $\mathrm{z}$ wirusa. Jest to reakcja komórkowej cytotoksyczności zależnej od przeciwciał (ang. antibody-dependent cellular cytotoxicity, ADCC). Organizm odnosi bezpośrednia korzyść z działania komórek NK i CD8+, niszczącego komórki zainfekowane wirusem (w tym SARS-CoV-2), gdyż przestają one być źródłem nowych czastek wirusa i zmniejsza się szansa na infekcje kolejnych podatnych komórek. Niestety lityczna (prowadzaca do rozpadu, z uwolnieniem składników cytoplazmy, jądra komórkowego i organelli) śmierć zainfekowanej komórki wymierzona przez NK czy limfocyty CD8+ jest źródłem silnego sygnału prozapalnego $\mathrm{w}$ postaci uwalnianych $\mathrm{z}$ niszczonych komórek grup czasteczek zwanych wzorcami molekularnymi związanymi z uszkodzeniem komórki (ang. damage-associated molecular patterns, DAMP). Jednym z ważniejszych DAMP jest białko HMGB1, które praktycznie od początku historii $\mathrm{CO}$ VID-19 zaczęło być uważane za istotny czynnik prozapalny, ale i potencjalny cel (target) terapii tej choroby (ANDERSSON i współaut.
2020, CHEN i współaut. 2020). Po uwolnieniu $\mathrm{z}$ niszczonej przez mechanizmy cytotoksyczne komórki, HMGB1 (i inne DAMP) wiaża się $z$ receptorami na powierzchni komórek prozapalnych, takich jak monocyty, makrofagi, komórki dendrytyczne i neutrofile, prowadzac do ich aktywacji (w tym sekrecji cytokin prozapalnych, chemokin i enzymów), co napędza proces zapalny i uszkadza tkanke. Receptorem dla HMGB1 jest białko RAGE (ang. receptor of advanced glycation endproducts), wiażące wspomniane $\mathrm{w}$ jego nazwie zaawansowane produkty glikacji. Ta wiedza przyda się nam do zrozumienia cięższych skutków infekcji SARS-CoV-2 u osób starszych, co zostanie wyjaśnione w dalszej częśsi artykułu.

Uszkodzenie i lityczne zniszczenie komórek zainfekowanych przez SARS-CoV-2, czego konsekwencja jest uwolnienie HMGB1 i innych DAMP oraz podsycanie procesu zapalnego, może następować także pod wpływem humoralnego mechanizmu zależnego od kaskady białek dopełniacza. Tu klasycznie wymagane jest uprzednie zwiazanie odpowiednich przeciwciał $z$ antygenami wirusa na powierzchni zainfekowanej komórki; do tych przeciwciał wiąża się kolejne białka dopełniacza (kaskadowo). Zwiazanie pierwszego z nich prowadzi do jego aktywacji i umożliwia przywiazanie i aktywację kolejnego; ostatecznie w błonie zainfekowanej komórki pojawiaja się kanały utworzone $z$ cząsteczek białka C9 kompleksu dopełniacza, przez które do wnętrza komórki napływa płyn pozakomórkowy zmieniając ciśnienie osmotyczne i rozsadzając komórkę od środka.

Jednak proces zapalny w odpowiedzi na wniknięcie do komórki wirusowego RNA (w tym pochodzacego $z$ SARS-CoV-2) może być zainicjowany także wówczas, gdy infekowana komórką będzie zwłaszcza monocyt lub któraś forma makrofaga (napływowa infiltrująca zainfekowana tkankę czy też rezydyjaca), a także komórki dendrytyczne i limfocyty B. Materiał genetyczny wirusa jest rozpoznawany przez wewnatrzkomórkowe formy receptorów Toll-podobnych (ang. Toll-like receptors, TLR): TLR3, TLR7 i TLR9. Ścieżki metaboliczne zainicjowane przez kontakt tych receptorów $z$ materiałem genetycznym infekujacego koronawirusa prowadza do aktywacji czynnika transkrypcyjnego NF-kB, która inicjuje syntezę i sekrecję cytokin prozapalnych.

$Z$ wyjatkiem limfocytów cytotoksycznych T CD8+, wszystkie pozostałe komórki wymienione jako zaangażowane $\mathrm{w}$ proces neutralizacji wirusów (w tym SARS-CoV-2) należą do komórek odporności wrodzonej. Ich ochronne działanie prowadzi do powstania reakcji zapalnej. 
Antygeny wirusowe rozpoznawane sa także przez tzw. pomocnicze limfocyty $\mathrm{T}$ (CD4+). W tym celu muszą być zaprezentowane kompleksowi receptora dla antygenu na limfocycie CD4+, tzw. TCR/CD3, wraz z antygenem zgodności tkankowej HLA (tym razem inaczej niż w przypadku limfocytów CD8+, czyli HLA klasy II). Ten z kolei znajduje się na tzw. komórkach prezentujących antygen, do których należą komórki dendrytyczne, monocyty/makrofagi, neutrofile, keratynocyty, a także aktywne limfocyty B i T. Skutkiem aktywacji pomocniczych limfocytów $\mathrm{T}$ jest produkcja wielu cytokin, które zwrotnie pobudzają komórki odpowiedzi wrodzonej do skuteczniejszej walki $z$ wirusowym patogenem, stymuluja inne pomocnicze (i oczywiście cytotoksyczne) limfocyty T, a wreszcie działaja stymulujaco na limfocyty B wyposażone w swoiste dla antygenów danego wirusa receptory $\mathrm{BCR}$, decydujac o ich klonalnej proliferacji, konwersji do komórek plazmatycznych i produkcji przeciwciał. Te ostatnie w trakcie dojrzewania odpowiedzi humoralnej, co wiąże się m.in. z dodatkowymi zjawiskami w genach części zmiennych łańcuchów ciężkich tychże przeciwciał, uzyskuja coraz większa precyzję wiązania $z$ antygenem i nabywaja większego powinowactwa do odpowiednich epitopów. W trakcie dojrzewania odpowiedzi humoralnej dochodzi wreszcie do tzw. przełaczania klas, co prowadzi do zastapienia produkcji najwcześniejszej klasy immunoglobulin, czyli IgM, przez kolejne klasy (IgG, IgA, IgE), a to dalej podnosi skuteczność układu odpornościowego w walce $z$ wirusami.

Powyższe informacje moga się wydawać oczywiste przynajmniej części czytelników, którzy znaja podstawy immunologii. Sa one jednak niezbędne, aby (w dużym skrócie i uproszczeniu) pokazać, że skuteczna odporność przeciwwirusowa (w tym przeciwko SARS-CoV-2) wymaga skoordynowanej w czasie i przestrzeni (rozumianej jako miejsce infekcji i lokalne narządy limfatyczne) aktywności wielu rodzajów komórek odpornościowych oraz ich produktów. Pozwolą także zrozumieć czytelnikowi, jak wiek osoby zainfekowanej przez SARS-CoV-2 wpływa na reakcje jej układu odpornościowego, a w konsekwencji na przebieg COVID-19.

\section{FORMY OSTREGO I PRZEWLEKEEGO COVID-19}

Wirus SARS-CoV-2 wnika do organizmu ludzkiego głównie droga kropelkowa, dostając się w kropelkach aerozolu do górnych dróg oddechowych poprzez jamę nosowa czy jamę ustną; infekcja może także rozpoczać się od spojówek oka (Wu i współaut. 2021).
Wykazano także, że wirus zachowuje zakaźność nawet przez kilka dni po opadnięciu aerozolu na suche powierzchnie i możliwe jest więc również zakażenie drogą dotykowa. Charakterystycznym powierzchniowym białkiem wirusa, umożliwiającym mu przyczepienie się do powierzchni zarażanych komórek, jest białko kolca (ang. spike; stąd białko S). Białko to wiaże się $z$ obecnymi na powierzchni zarażanych komórek cząsteczkami receptora $z$ rodziny konwertazy angiotensyny o symbolu ACE2. Takie wiązanie umożliwia endocytozę czastek wirusa, który dostaje się do wnętrza komórki w pęcherzykach endocytarnych. Te $z$ kolei wiąża się $z$ lizosomami, w których wnętrzu zachodzi częściowa degradacja wirionów i uwolnienie materiału genetycznego (RNA) wirusa do cytoplazmy. Alternatywna droga wnikania wymaga współpracy kompleksu białka S i ACE2 $z$ przezbłonowa serynowa proteaza typu II TMPRSS2, która modyfikuje białko $\mathrm{S}$ tak, aby zwiększyć jego powinowactwo do ACE2 (WU i współaut. 2021). SARS-CoV-2 nie jest retrowirusem, dlatego replikacja jego materiału genetycznego (a w konsekwencji całego wirusa) nie wymaga odwrotnej transkrypcji wirusowego genomu (RNA) i integracji powstałego DNA do genomu zainfekowanej komórki. Do takiej komórki wnika jednoniciowe, genomowe RNA wirusa, które natychmiast ulega translacji do dwóch poliproteinowych kompleksów ORF1a i ORF1b, z których, dzięki dalszym modyfikacjom w cytoplazmie, powstaja białka tworzace „maszynerię" niezbędna do replikacji wirusowego genomu, w tym białko RdRP - zależna od (wirusowego) RNA polimerazę RNA (V'KovSKI i współaut. 2021). Nowe kopie wirusowego RNA sa otaczane przez białka wirionu nowo wytworzone w komórce na bazie kodu RNA. Ostatecznie gotowe cząsteczki wirusa opuszczaja komórkę droga egzocytozy i trafiaja do płynów biologicznych, skąd moga infekować kolejne komórki. Podsumowując, wszystkie rodzaje komórek posiadajacych na swojej powierzchni ACE2, a tym bardziej takie, które dodatkowo maja TMPRSS2, moga zostać zainfekowane przez SARS-CoV-2 i stać się miejscem jego replikacji. Na początku „historii naturalnej” COVID-19 badaczom i lekarzom wydawało się, że jest to względnie "typowa" (choć ostra i często niebezpieczna dla życia) infekcyjna i zapalna choroba płuc. Wkrótce jednak zaczęły pojawiać się doniesienia (opisy przypadków zachorowań na COVID-19, a potem całych ich serii), gdzie infekcja i zapalenie płuc oraz jego skutki, czyli duszność i niedotlenienie tkanek, zostawały uzupełnione o zaburzenia działania jelit, serca, nerek, wątroby, mózgu i wydłużającej się listy innych narządów, co 
oczywiście pogarsza stan takich chorych i utrudnia ich leczenie. Szybko przekonano się, że zaburzenia pracy wymienionych narządów nie wynikaja tylko $z$ niedostatecznego utlenowania docierajacej do nich krwi w uszkodzonych płucach, chociaż z pewnościa ten element patomechanizmu COVID-19 jest również ważny. Okazało się bowiem, że ACE2 (często $z$ towarzyszacym TMPRSS2) jest bardzo popularnym wyposażeniem powierzchni wielu typów komórek naszego organizmu [w tym nabłonka węchowego, nabłonka jelit (enterocytów), kardiomiocytów tworzących mięsień serca, komórek nefronu w nerkach, hepatocytów, a także neuronów $\mathrm{i}$ astrocytów w mózgu i innych] (KERSLAKE i współaut. 2020). Co gorsza, ACE2 jest obecne także na powierzchni komórek śródbłonka, wyścielających wszystkie naczynia krwionośne, i towarzyszacych im pericytów, tworzacych sieć kapilar (naczyń włosowatych) rozprowadzajacych krew bogata w tlen i składniki odżywcze, a odbierajacych produkty przemiany materii ze wszystkich tkanek. SARS-CoV-2 jest zdolny do infekcji komórek śródbłonka i uszkadzania ich funkcji, co $z$ jednej strony bezpośrednio upośledza funkcje tkanek, $z$ drugiej, może prowadzić do agregacji płytek krwi i procesów krzepnięcia, co dalej pogarsza sytuację w narządach (LEI i współaut. 2021). Pogarsza się ona tym bardziej, gdyż reakcje zapalne wynikajace $z$ omówionych powyżej aktywności komórek zapalnych i działania wydzielonych przez nie cytokin prozapalnych będa „uderzały” także w śródbłonki, których komórki sa wyposażone w receptory dla cytokin prozapalnych. Można więc (znowu w uproszczeniu) powiedzieć, że COVID-19 jest ostra zapalną chorobą wielonarządową o silnej komponencie uszkodzenia układu oddechowego i sercowo-naczyniowego, $z$ domieszka (często istotna klinicznie) uszkodzeń innych układów ciała, czyli do wielonarządowej niewydolności, która może się skończyć śmiercią pacjenta (LI i współaut. 2020). Najbardziej niebezpieczne stany będace konsekwencją infekcji SARS-CoV-2 to zawał serca lub jego ostra niedomoga, udar mózgu, ostra niewydolność nerek i/lub watroby.

Jednak objawy ostrego COVID-19 to nie tylko powyższe stany zagrażajace życiu. Wśród pierwszych objawów tej choroby opisywano przede wszystkim gorączkę, suchy kaszel, bóle mięśni, osłabienie i utratę węchu, a w przypadku osób wymagajacych hospitalizacji zwłaszcza narastająca duszność, $a \dot{z}$ do pełnoobjawowego zespołu ostrej niedomogi oddechowej ARDS, jednak ta symptomatologia zmienia się wraz $z$ pojawianiem się nowych wariantów (mutantów) patogenu. I tak, jednym $z$ charakterystycznych obja- wów zakażenia wariantem brytyjskim SARS-CoV-2 jest długotrwałe, a często nieodwracalne uszkodzenie słuchu na tle neurologicznym; częstsze sa także inne zaburzenia neurologiczne i psychiatryczne, a dotychczas dominujace objawy ostrej infekcji SARS-CoV-2 wydaja się odchodzić na dalszy plan (co oczywiście nie oznacza, że znikaja).

\section{„LONG COVID” (LC), CZYLI PÓŹNE} PO"WIKEANIA I NASTEPSTWA INFEKCJI SARS-COV-2

W tytule tego podrozdziału świadomie użyłem słowa „infekcji”, a nie „przechorowania”, ponieważ zaobserwowano, że LC może wystapić także u tych, którzy ostra fazę infekcji przeszli bezobjawowo. Badacze zagadnienia uważają, że LC dotyczy nawet ponad $10 \%$ wszystkich osób zainfekowanych przez SARS-CoV-2. Za powikłania o charakterze LC uważa się takie objawy, które trwaja co najmniej 4 tygodnie od rozpoznania infekcji (bądź przechorowania), przy czym moga one utrzymać się przez wiele miesięcy. Do tych objawów i powikłań COVID-19 o niewielkim nasileniu objawów należą: długotrwałe znaczne zmęczenie, osłabienie mięśni, stany podgoraczkowe, kłopoty $z$ koncentracja, pamięcia, zaburzenia nastroju i snu, bóle głowy, parestezje (niewłaściwe odczuwanie bodźców), kłopoty $Z$ połykaniem (dysfagia), biegunka, wymioty, przetrwała utrata węchu i/lub smaku, rumień skórny, bóle zamostkowe, palpitacje serca, a także wystapienie objawów cukrzycy i nadciśnienia tętniczego (YONG 2021).

Z kolei w przypadku osób, które przeżyły ciężki COVID-19, objawy LC dotycza płuc (zwłóknienie, prowadzace do niedomogi oddechowej), serca (objawy wieńcowe, ale także przewlekłe zapalenia mięśnia sercowego) oraz ośrodkowego układu nerwowego, gdzie objawy LC moga polegać na zawrotach głowy, nerwobólach, a także zaburzeniach świadomości (JESUTHASAN i współaut. 2021, Yong 2021). Potencjalnym zagrożeniem wynikajacym $z$ przetrwałego uszkodzenia składników układu krążenia, a także nasilonego stanu zapalnego (ang. inflammaging, patrz niżej) może być - sugerowany przez lekarzy - wzrost częstości chorób neurodegeneracyjnych wieku podeszłego, takich jak choroba Alzheimera czy Parkinsona. W przypadku tej pierwszej postuluje się, że jednym z czynników wyzwalajacych jej powstanie sa nawracajace infekcje zarówno w samym mózgu, jak też na obwodzie. Wykazano bowiem, że beta-amyloid (Ab), tworzacy agregaty w tkance mózgowej wywołujace jej zapalenie, jest peptydem o aktywności skierowanej przeciwko patogenom trafiającym do mózgu: 
wirusom, bakteriom czy chorobotwórczym drożdżakom (BOURGADE i współaut. 2016). Ta aktywność polega na zlepianiu ze soba jego czasteczek, a w takich agregatach grzęzna patogeny. Niestety agregaty $\mathrm{Ab}$ stymuluja procesy zapalne w mózgu (aktywność mikrogleju, który jest lokalna forma makrofagów), co prowadzi do uszkodzeń neuronów i rozszczelnienia bariery krew-mózg (ang. blood-brain barier, BBB). To umożliwia napływ do mózgu innych komórek odpornościowym $z$ obwodu i nasila procesy zapalne. Podobnie, infekcje na obwodzie, prowadzace do odczynu zapalnego i wydzielania cytokin prozapalnych, również rozszczelniają BBB, ułatwiając zarówno komórkom odpornościowym, cytokinom, jak i krażacym patogenom dostęp do tkanki mózgowej i napędzając błędne koło prowadzące do nasilającej się neurodegeneracji i, po wielu latach, choroby Alzheimera (JozWIK i współaut. 2012, FULOP i współaut. 2018a, LE PAGE i współaut. 2018a, MunAWARA i współaut. 2021). Lista patogenów mogacych uczestniczyć w indukcji procesów neurodegeneracyjnych nie jest w pełni poznana (badania trwaja), ale na pewno choroba nie jest wynikiem jakiejś konkretnej infekcji przez określony patogen, a reakcja na sumę tych infekcji na obwodzie i w mózgu (Fulop i współaut. 2020b, 2021). Ponieważ SARS-CoV-2 jest rozpoznawany przez (i może infekować) komórki mikrogleju, a także astrogleju oraz śródbłonka tworzacego BBB, gdyż wszystkie te typy komórek posiadają na swojej powierzchni receptory ACE2 i TMPRSS2, jego dotarcie do mózgu może prowokować odpowiedź typu zapalnego nieco podobna do wywoływanej w mózgu przez wirusa HIV i prowadzacej do zmian otępiennych towarzyszacych zaawansowanym przypadkom tej choroby (FULOP i współaut. 2019b, TORICES i współaut. 2021).

Objawy te, występujace w warunkach, gdy organizm nie powinien już zawierać replikującego się wirusa, wydają się mieć jedną wspólną cechę: u podłoża większości $z$ nich leży przewlekły stan zapalny, być może (w przypadku osób, które przeżyły ciężki przebieg choroby) zależny m.in. od wystapienia "burzy cytokinowej” (Hu i współaut. 2021, Pum i współaut. 2021). Polega ona na gwałtownym pobudzeniu dużej liczby komórek odpornościowych zdolnych do produkcji cytokin prozapalnych (takich jak IL-1, IL6, czynnik martwicy nowotworów-a (TNF-a), GM-CSF, IL-8, IL-10 i inne) i ich masywnej sekrecji. W odpowiedzi, pobudzeniu ulegaja inne komórki odpornościowe, a ostateczny efekt to wspomniane wyżej wielonarzadowe uszkodzenia poprzez działanie samych cytokin na różne typy komórek w uszkadzanych narząach, a także w wyniku działania ak- tywowanych przez cytokiny komórek cytotoksycznych i żernych (fagocytujących).

$Z$ tego względu dobrze jest wiedzieć, że na szczęście tylko pewien odsetek osób zainfekowanych (wg różnych badań od kilku do parudziesięciu procent) manifestuje objawowy COVID-19 i tylko kilka procent spośród chorych rozwija ciężka postać choroby. Na razie (wrzesień 2021) nie sa znane przyczyny różnych reakcji poszczególnych osób na kontakt $z$ koronawirusem. Postulowane sa zróżnicowanie genetyczne, równowaga (lub jej brak) w obrębie układu odpornościowego, immunobiografia (czyli suma wszystkich wyzwań, z jakimi układ odpornościowy danej zainfekowanej osoby zetknął się wcześniej), obecność chorób współistniejacych (istotna zwłaszcza, ale nie wyłacznie, dla przebiegu COVID-19 u osób w podeszłym wieku) i inne; obecnie prowadzone sa liczne badania majace pomóc lekarzom i badaczom zrozumieć różnice $\mathrm{w}$ przebiegu infekcji SARS-CoV-2 i przewidzieć ten przebieg. Na razie jednak brak jednoznacznych danych na temat potencjalnych biomarkerów pozwalających na takie przewidywania.

\section{STARZENIE SIE UKŁADU ODPORNOSCIOWEGO I JEGO SKUTKI W KONTEKŚCIE COVID-19}

Podobnie jak wszystkie inne systemy tworzace nasze organizmy, także układ odpornościowy ulega rozlicznym zmianom $z$ upływem lat, które szczególnie przyspieszaja w wieku starszym (umownie po 65. roku życia). Konsekwencją tych zmian w układzie odpornościowym jest rosnaca częstość i ciężki przebieg infekcji, rosnaca liczba nowotworów (w tym nowotworów złośliwych), a także rosnacca liczba reakcji autoimmunologicznych (które jednak nie muszą oznaczać klinicznej choroby autoimmunizacyjnej). Zmniejsza się także skuteczność szczepień, chociaż to stwierdzenie jest ostatnio podważane przez badania wykazujace, że specjalnie skonstruowane szczepionki (więcej antygenu, modyfikowane adjuwanty) moga wytworzyć u starszych osób odporność nie gorszą niż konwencjonalne szczepionki u ludzi młodych.

Przyczyny tych zmian w starzejacym się układzie odpornościowym sa złożone. $Z$ jednej strony starzeniu (senescencji) podlegaja komórki odpornościowe, podobnie jak inne komórki organizmu. Senescencja komórek odpornościowych (immunosenescencja; ang. immunosenescence) dotyka wszystkich ich typów, ale w szczególności uderza w limfocyty T i B, czyli komórki odporności nabytej (adaptacyjnej). Polega ona na zmniejszonej zdolności do proliferacji (czyli wytwarzania komórek efektorowych) T CD4+ i CD8+, a 
także limfocytów B w odpowiedzi na kontakt $z$ antygenem, co oczywiście zmniejsza efektywność odpowiedzi, także przeciwko SARS-CoV-2. Mniej komórek cytotoksycznych CD8+ to zmniejszona efektywność niszczenia komórek zainfekowanych, mniej pomocniczych CD4+ to mniej czynników wzrostu (cytokin) dla limfocytów T, NK i B, czyli znowu obniżona efektywność cytotoksycznej eliminacji zarażonych komórek, ale też zmniejszone miano przeciwciał mogacych ułatwić neutralizację wirusa, zarówno jeszcze znajdującego się pozakomórkowo, jak i (pośrednio poprzez wspomniana reakcję ADCC) już replikującego się w komórkach. Klony limfocytów powstajace $\mathrm{w}$ wyniku stymulacji przez antygeny wirusowe sa coraz mniejsze. Można to oceniać poprzez pomiary częstości występowania określonych form receptora dla antygenu TCR. W uproszczeniu, wielokrotne „użycie” komórek pamięci pochodzacych $\mathrm{Z}$ danego klonu powoduje $z$ czasem ich wyczerpanie i znaczna redukcję lub nawet zanik odpowiedzi limfocytów na dany epitop wirusowy. Ten stan określany jest jako kurczenie się repertuaru TCR u osób w podeszłym wieku (NAYLOR i współaut. 2005). Należy jednak podkreślić, że na razie nie opisano tego efektu jako czynnika redukujacego efektywność odpowiedzi limfocytów $\mathrm{T}$ wobec SARS-CoV-2 (być może $z$ powodu względnie krótkiego okresu koegzystencji $H$. sapiens $z$ tym koronawirusem). Powyższym zmianom ilościowym towarzysza zmiany jakościowe - zaburzenia w ścieżkach wewnątrzkomórkowej sygnalizacji, co zmienia (zwykle upośledza) odpowiedź indywidualnych limfocytów na stymulację; tak więc nawet jeśli liczba komórek $\mathrm{T}$ rozpoznajacych antygeny SARS-CoV-2 byłaby wystarczajaca u osób w podeszłym wieku, to wielkość ich odpowiedzi będzie mniejsza niż obserwowana u osób młodych (FULOP i współaut. 2014, LE PAGE i współaut. 2018b).

Aby doszło do skutecznej (neutralizującej) odpowiedzi na antygeny nowego patogenu, jakim jest SARS-CoV-2, niezbędne jest istnienie dużej liczby naiwnych limfocytów $\mathrm{T}$, posiadajacych receptor rozpoznajacy te właśnie antygeny, wytworzony w drodze hipermutacji i rekombinacji w obrębie genów tworzacych łańcuchy TCR. Liczba tych komórek jest prawdopodobnie duża u dzieci, ponieważ, dzięki aktywności grasicy (tymopoeza), wśród ich limfocytów $\mathrm{T}$ zdecydowanie przeważaja komórki naiwne. Natomiast zmniejsza się w zwiazku $z$ inwolucja (zanikiem) grasicy rozpoczynajaca się w okresie pokwitania, tak więc wśród limfocytów krwi obwodowej (i prawdopodobnie rezydujacych w narządach limfatycznych) u osób starszych może być nawet o parę rzędów wielkości mniej naiwnych limfocytów T (w tym oczywiście mogacych rozpoznać antygeny SARS-CoV-2) (KOETZ i współaut. 2000). Wśród limfocytów T osób w podeszłym wieku przeważaja limfocyty pamięci immunologicznej, co oczywiście pomaga zwalczyć infekcje powodowane przez patogeny, z którymi organizm zetkną się wcześniej. W przypadku infekcji SARS-CoV-2 takie uprzednie zetknięcie mogłoby oczywiście wytworzyć komórki pamięci u ozdrowieńców, a także u osób zaszczepionych. Jednak u osób w podeszłym wieku jest mniej limfocytów naiwnych, które mogłyby odpowiedzieć na pierwszy kontakt $z$ wirusem, zneutralizować go i wytworzyć pulę limfocytów pamięci. Dlatego także szczepienia u tych osób sa (moga być) mniej efektywne. Należy tu jednak podkreślić, że nie jest to powód zaniechania szczepień w tej grupie wiekowej. Wręcz przeciwnie, osoby ze starszych grup wiekowych powinny się zaszczepić jak najszybciej, w miarę możności zbadać poziom przeciwciał anty-SARS-CoV-2 i w razie potrzeby doszczepić się w celu uzyskania wystarczajacej ochrony.

Oprócz wzrostu proporcji komórek pamięci immunologicznej kosztem komórek naiwnych, co zmniejsza szanse na rozpoznanie antygenów SARS-CoV-2 i swoista reakcje w stosunku do nich, wśród limfocytów osób w podeszłym wieku dochodzi także do wzrostu odsetka komórek regulatorowych wywodzacych się z limfocytów T, tzw. Treg, hamujących nadmierna i już chwilowo niepotrzebna odpowiedź immunologiczna (BRYL i WITKOWSKI 2004, BRYL i współaut. 2009). Względny wzrost odsetka Treg, nawet jeśli proces starzenia komórkowego $z$ pewnościa dotyka także i tę populację limfocytów, może wpływać hamujaco na efektywność odpowiedzi anty-SARS-CoV-2 u osób starszych.

Podsumowujac, w uproszczeniu immunosenescencja będzie prowadziła do zmniejszenia swoistej, adaptcyjnej odpowiedzi immunologicznej wobec SARS-CoV-2 u osób w podeszłym wieku. Dlaczego więc ci chorzy maja większe ryzyko rozwinięcia objawowego, a następnie ciężkiego COVID-19?

Trzeba zauważyć, że immunosenescencja limfocytów polega jednak nie tylko na zmniejszonej zdolności do proliferacji, wynikającej zarówno z zaburzeń sygnalizacji wewnątrzkomórkowej, jak i niedoboru cytokin wzrostowych takich jak IL-2 i IL-4. Towarzyszy jej charakterystyczna dla wszystkich komórek starzejacych się (senescentnych) nadprodukcja cytokin prozapalnych. Komórki senescentne uzyskują fenotyp $z$ ang. określany jako senescence-associated secretory phenotype (SASP), polegajacy właśnie na produkcji i sekrecji cytokin prozapalnych (niezależnie od tego, jaka była rola i właściwości danej komórki zanim uległa ona senescencji). Pojawienie się i gromadzenie komórek o tym 
fenotypie będzie jedna $z$ przyczyn powstania zjawiska inflammaging, omówionego poniżej.

Należy pamiętać, że zaburzenia prowadzace do immunosenescencji i innych zmian towarzyszacych starzeniu się układu odpornościowego nie sa wyłącznie wynikiem zmian majacych przyczyny w samym układzie odpornościowym. I tak, reakcje odpornościowe, które wymagaja wytworzenia de novo milionów komórek i bilionów cząsteczek biologicznie aktywnych (cytokin i przeciwciał), wymagaja energii umożliwiającej procesy metaboliczne, czyli ATP. Do tego potrzebne sa $z$ jednej strony sprawne, wysoko wydajne mitochondria, a trzeba pamiętać, że aktywne limfocyty przestają używać do produkcji ATP fosforylacji oksydatywnej, zastępujacc ja znacznie mniej wydajna glikoliza tlenowa (jest to tzw. efekt Warburga) (YANG i CHI 2012, STARK i współaut. 2015). W starzejacych się limfocytach obniża się liczba i wydajność mitochondriów, czyli produkują one mniej ATP w stosunku do zapotrzebowania. Skutkiem tego obniża się metabolizm limfocytów i ich funkcjonalność. Dzieje się tak zreszta nie tylko w starzejacych się limfocytach, ale we wszystkich starzejących się komórkach. $Z$ tego względu zaburzenia w mitochondriach zostały właczone do dziewięciu tak zwanych filarów (charakterystycznych cech) starzenia się, wraz ze skróceniem telomerów, zaburzeniami ścieżki mTOR, zaburzeniami proteostazy, senescencja komórkowa per se, zaburzeniami epigenetycznymi, niestabilnością genetyczna, zaburzeniami komunikacji między- i wewnątrzkomórkowej i wreszcie wyczerpaniem komórek macierzystych (LOPEZ-OTIN i współaut. 2013). Warto tutaj powiedzieć, że praktycznie wszystkie te „filary” występuja w trakcie starzenia się komórek układu odpornościowego i prowadza do jego dysfunkcji. Druga przyczyna zaburzonej gospodarki energetycznej, mogacej wpływać na odporność u osób w podeszłym wieku, jest niedożywienie (głównie białkowe), prowadzace do niedoboru substratów do budowy nowych komórek i ich produktów, niestety typowe w tej grupie wiekowej. Co gorsza, zmniejszonej produkcji ATP w starych komórkach (w tym odpornościowych) towarzyszy wzrost produkcji wolnych rodników tlenowych (reaktywnych form tlenu, ang. reactive oxygen species, ROS), które w nadmiarze prowadza do stresu oksydacyjnego i uszkodzeń różnych typów cząsteczek w komórkach, co pogłębia dysfunkcje zależne od wieku.

\section{ZABURZENIA OSI NEURO- ENDOKRYNO-IMMUNOLOGICZNEJ}

Jednym ze wspomnianych filarów starzenia sa zaburzenia komunikacji międzyko- mórkowej. Należy tu wspomnieć o istnieniu integracyjnej triady układów w naszym organizmie, złożonej $\mathrm{z}$ układu odpornościowego, dokrewnego i nerwowego. Ich składniki komórkowe (neurony, komórki wydzielające hormony i komórki odpornościowe) komunikuja się ze soba i wzajemnie reaguja na swoje sygnały (odpowiednio neuromediatory, hormony i cytokiny), dzięki posiadanym receptorom i ścieżkom metabolicznym. W przypadku starzejącego się układu odpornościowego zaburzenia tej triady maja wielkie znaczenie, gdyż $z$ jednej strony białkowe produkty tego układu [cytokiny wydzielane w nadmiarze (inflammaging)] moga nadmiernie interferować $z$ funkcja układu nerwowego (prawdopodobnie prowadzac m.in. do zaburzeń neurologicznych obserwowanych w przebiegu long COVID), a $z$ drugiej, starzejacy się układ nerwowy o zmienionym spektrum neuromediatorów, a także generalnie zmniejszona produkcja wielu hormonów, moga niewłaściwie regulować funkcje układu odpornościowego u starszej osoby, co także może wpływać na jej odporność wobec SARS-CoV-2.

\section{INFLAMMAGING}

Powyżej już parokrotnie użyto terminu „inflammaging”. Termin ten wprowadził do obiegu ponad 2 dekady temu wybitny włoski gerontolog Claudio Franceschi, definiując inflammaging jako stan, w którym w organizmie starzejaccej się osoby pojawiaja się podwyższone (na granicy normy lub nieco powyżej) stężenia cytokin prozapalnych (IL1, IL-6, TNFa i in.), niezwiazane $z$ zaistnieniem infekcji, urazu, nowotworu czy jakiejkolwiek innej sytuacji indukujacej proces zapalny i prowadzacej do choroby zapalnej (FRANCESCHI i współaut. 2000). Od tej pory powstały setki prac wskazujacych nie tylko na względna popularność zjawiska inflammaging u starzejacych się ludzi, ale także mechanizmy jego powstania i wpływ na stan ich zdrowia. Jeśli chodzi o mechanizmy inflammaging, to $z$ jednej strony podnoszona jest rola gromadzących się w starzejacym organizmie komórek senescentnych o fenotypie SASP (wspomnianym wcześniej), polegającym właśnie na przewlekłej sekrecji cytokin prozapalnych niezależnie od tego, jakie jest pochodzenie danej komórki. $Z$ drugiej strony, źródłem cytokin prozapalnych moga być i oczywiście sa komórki odporności wrodzonej [głównie monocyty, makrofagi, komórki dendrytyczne i w mniejszym stopniu neutrofile (ze względu na krótki okres życia)]. Podstawowym efektem pobudzenia odporności wrodzonej (np. przez bakterie) jest uruchomienie zjawisk zapalnych jako skutecznego 
sposobu ograniczania i neutralizacji infekcji. W starzejacym się organizmie gdzie, jak powiedziano wyżej, zmniejsza się efektywność odpowiedzi nabytej wobec antygenów (np. wirusowych), odporność wrodzona staje się głównym sposobem neutralizacji patogenu. Pomaga w tym niedawno odkryte zjawisko tzw. wytrenowanej pamięci (ang. trained memory, trained immunity) makrofagów, które na kolejne kontakty $z$ patogenem odpowiadaja silniej niż na poprzedzające (TERCAN i współaut. 2021). Jest ono zwiazane ze wspomnianym wcześniej pojęciem immunobiografii, czyli historii wszystkich spotkań układu odpornościowego danej osoby $z$ patogenami, pozostawiającej ślady zarówno $\mathrm{w}$ zachowaniu komórek odporności wrodzonej, jak też nabytej (tu chodzi oczywiście o komórki pamięci). W konsekwencji nawet subkliniczna infekcja może prowadzić u starszych osób do wyrzutu dużych ilości prozapalnych cytokin i podtrzymania inflammaging. Kolejnym czynnikiem mogacym stymulować komórki odporności wrodzonej (a częściowo także nabytej) jest ligacja receptorów dla końcowych produktów glikacji - RAGE (wspomnianych wyżej). Z wiekiem w organizmie starzejacego się człowieka pojawia się coraz więcej AGE, produktów nieenzymatycznego dodawania reszt glukozowych do czassteczek białek, lipidów, a nawet kwasów nukleinowych, oraz ich metabolitów. Proces zachodzi nawet $\mathrm{u}$ osób $\mathrm{z}$ normalnym stężeniem glukozy we krwi i oczywiście nasila się u chorych na cukrzycę, zwłaszcza typu 2. Cukrzyca, podobnie jak otyłość, nadciśnienie tętnicze i nowotwory złośliwe, należy do najistotniejszych czynników ryzyka ciężkiego przebiegu i śmiertelności COVID-19. Sa to tzw. choroby towarzyszace, wszystkie o mniej lub bardziej oczywistym podłożu przewlekłego zapalenia, będace typowymi chorobami zwiazanymi ze starzeniem (ang. aging-related diseases, ARDs). Wykazano, że w ich patogenezie istotna rolę pełni właśnie gromadzenie się AGE. Receptory RAGE sa obecne na leukocytach i ich ligacja stymuluje aktywacje tych komórek i m.in. produkcję cytokin prozapalnych. Co ciekawe, RAGE odkryto także na powierzchni pneumocytów typu II w pęcherzykach płucnych, czyli komórek, które jako pierwsze zostały zidentyfikowane jako cel ataku SARS-CoV-2. Obecnie podnoszona jest możliwość, że względny nadmiar AGE u osób starszych silniej pobudza RAGE (nie tylko, co oczywiste, w leukocytach, ale także w pneumocytach), prowadzac do ich dysfunkcji i cięższego przebiegu choroby u osób starszych (SELLEGOUNDER i współaut. 2021). Podsumowujac, zjawiska immunosenescencji i inflammaging sa wynikiem długotrwałej interakcji komórek odpornościowych z patogenami i rozregulowania odpowiedzi immunologicznej w kontekście działania innych układów starzejącego się organizmu (TAHAGHOGHI-HAJGHORBANI i współaut. 2020). Prowadza one do przesunięcia „środka ciężkości" reakcji odpornościowej wobec patogenu (w tym wobec SARS-CoV-2) z reakcji adaptacyjnej (która ulega obniżeniu w drodze immunosenescencji i wyczerpania) do reakcji należących do odporności wrodzonej (która nasila się prowadząc do inflammaging, a następnie do przewlekłych chorób zapalnych ARDs). W tym kontekście inflammaging może być do pewnego stopnia traktowany jako proces adaptacji układu odpornościowego starszych osób, na swój sposób chroniacy je przed infekcjami kosztem rozwoju ARDs (FULOP i współaut. 2016, 2017, 2018b, 2019a, 2020a; WITKOWSKI i współaut. 2019). Infekcje SARS-CoV-2 sa groźne tylko dla niektórych osób dlatego, że dochodzi do uszkodzenia życiowo ważnych narząów w odpowiedzi na ostra lub (w long COVID) przewlekła, silną reakcję zapalna $z$ kulminacja $\mathrm{w}$ postaci burzy cytokinowej. Dlatego proponowane i już testowane klinicznie terapie COVID-19 maja na celu nie tylko działanie utrudniające infekcję i replikację SARS-CoV-2, ale także działania hamujace zarówno przyczyny, jak też efekty burzy cytokinowej.

Co interesujace, osoby, które ukończyły 100 lat lub więcej, wbrew intuicji, nie muszą chorować na COVID-19 ciężej niż osoby młodsze, a moga wręcz przejść kontakt $z$ SARS-CoV-2 bezobjawowo [tu przykładem (jednym $z$ wielu) może być najstarsza żyjaca Europejka, która skończyła 117 lat niedługo po wykryciu w jej surowicy przeciwciał skierowanych przeciwko SARS-CoV-2; https://www.nytimes.com/2021/02/10/world/ europe/sister-andre-covid19.html]. Najstarsi ludzie często zreszta cechują się wysokim poziomem markerów procesu zapalnego (OB, CRP) i cytokin prozapalnych; uważa się, że ich długowieczność ( $w$ tym zdolność do obrony przed infekcjami) wynika $z$ równowagi pomiędzy pożytecznymi, ale potencjalnie niebezpiecznymi zjawiskami zapalnymi a reakcjami przeciwzapalnymi.

\section{PODSUMOWANIE}

SARS-CoV-2 może zainfekować każdego, niezależnie od wieku. Najmłodsze osoby, u których wykazano infekcję nie ukończyły pierwszego roku życia, a najstarsze należą do „superstulatków”, czyli osób, które skończyty 110 i więcej lat. Konsekwencje infekcji, w tym wystapienie objawów i ciężkość przebiegu, konieczność hospitalizacji i intensywnej terapii, zależą od wieku. Pomimo pewnych 
zmian zwiazanych $z$ pojawianiem się nowych wariantów SARS-CoV-2, objawowy, a zwłaszcza ciężki przebieg COVID-19 jest najrzadszy $\mathrm{u}$ dzieci, a najczęstszy w grupie osób, które ukończyły 65 rok życia. Jest to zwiazane głównie $z$ inna struktura $i$ funkcjonalnościa układu odpornościowego. U małych dzieci układ odpornościowy dopiero uczy się rozpoznawania i neutralizacji patogenów (co ułatwia m.in. wysoki odsetek naiwnych limfocytów T $z$ grasicy) i SARS-CoV-2 jest tylko jednym $z$ wielu nowych czynników wywołujacym podobne jak inne wirusy, łagodne, a w większości bezobjawowe reakcje odpornościowe. Problem zaczyna się w wieku średnim, gdzie zaznaczaja się już procesy immunosenescencja i inflammaging, pojawiaja przewlekłe zapalne choroby towarzyszace starzeniu się, a stres $i$ inne przyczyny (m.in. zła dieta, dysbiozy mikrobioty jelitowej itp.) promuja stany zapalne. Sytuacja pogarsza się w wieku podeszłym, gdzie wymienione procesy i stany ulegaja nasileniu, na co nakładaja się procesy starzenia samych komórek odpornościowych i przesunięcie reaktywności immunologicznej wobec patogenu w kierunku reakcji zapalnej (co sprzyja ciężkiemu, zapalnemu przebiegowi COVID-19). Sposobem profilaktyki takiego przebiegu u osób starszych, podobnie jak w młodszych grupach wiekowych, może być skuteczne szczepienie, być może $z$ dawkami przypominajacymi, lub szczepionka specjalnie dostosowana do wymagań starzejącego się układu odpornościowego. Natomiast leczenie w tej grupie wiekowej powinno koncentrować się na hamowaniu nadmiarowych reakcji zapalnych, w tym na neutralizacji cytokin prozapalnych przez już dostępne leki biologiczne neutralizujace konkretne cytokiny prozapalne.

$$
\text { Streszczenie }
$$

Epidemiologiczne badania dotyczace nowej choroby koronawirusowej COVID-19 jednoznacznie wykazuja, że osobami bardziej niż inni narażonymi na objawowy, ciężki przebieg choroby, a także na śmierć w jej konsekwencji, sa osoby w podeszlym wieku. Osoby takie często cierpia na towarzyszace, zależne od starzenia, przewlekłe choroby zapalne, określane jako choroby wspólistniejace. Artykuł opisuje mechanizmy infekcji wirusem SARS-CoV-2 i rozwoju ostrego COVID-19 i formy przewlekłej określanej jako „long COVID” oraz udział różnych składników układu odpornościowego $\mathrm{w}$ rozwoju i przebiegu tej choroby $\mathrm{w}$ kontekście zmieniających się właściwości (starzenia) układu odporności wrodzonej i nabytej $u$ osób w podeszłym wieku. W szczególności uwzględniona w opisie jest rola dwóch procesów kluczowych dla starzenia się układu odpornościowego i powstawania chorób zależnych od starzenia się (w tym COVID-19): immunosenescencji i inflammaging.

\section{LITERATURA}

ANDERsson U., OTTESTAD W., TRACEY K. J., 2020. Extracellular HMGB1: a therapeutic target in severe pulmonary inflammation including $\mathrm{CO}$ VID-19? Mol. Med. 26, doi: 10.1186/s10020020-00172-4.

Bao C., Tao X., Cui W., Hao Y., Zheng S., Yi B., PAN T., YOUNG K. H., QIAN W., 2021. Natural killer cells associated with SARS-CoV-2 viral RNA shedding, antibody response and mortality in COVID-19 patients. Exp. Hematol. Oncol. 10, doi: 10.1186/s40164-021-00199-1.

Bourgade K., Le PAGE A., Bocti C., WitKowski J. M., Dupuis G., FROST E. H., FUlOP T. JR., 2016. Protective effect of amyloid-beta peptides against herpes simplex virus-1 infection in a neuronal cell culture model. J. Alzheimers Dis. 50, 1227-1241.

BRYL E., WiTKOWSKI J. M., 2004. Decreased proliferative capability of $\mathrm{CD} 4(+)$ cells of elderly people is associated with faster loss of activation-related antigens and accumulation of regulatory T cells. Exp. Gerontol. 39, 587-595.

BRYL E., DACA A., JOZWIK A., WiTKOWSKI J. M., 2009. Human CD4low CD25high regulatory $T$ cells indiscriminately kill autologous activated $T$ cells. Immunology 128, e287-e295.

CHEN R., HuANG Y., QUAN J. LIU J., WaNG H., BilliaR T. R., LOTZE M. T., ZEH H. J., KANG R., TANG D., 2020. HMGB1 as a potential biomarker and therapeutic target for severe COVID-19. Heliyon 6, doi: 10.1016/j.heliyon.2020.e05672.

FRANCESCHI C., BONAFE M., VALENSIN S., OlIVIERI F., De LuCa M., Ottaviani E., DE Benedictis G., 2000. Inflamm-aging. An evolutionary perspective on immunosenescence. Ann. NY Acad. Sci. 908, 244-254.

FuloP T., LE PAGE A., Fortin C., WitKowski J. M., DuPUIS G., LARBI A., 2014. Cellular signaling in the aging immune system. Curr. Opin. Immunol. 29, 105-111.

Fulop T., Dupuis G., Baehl S., Le Page A., BoURGADE K., FROST E., WITKOWSKI J. M., PAWELEC G., LARBI A., CUNNANE S., 2016. From inflamm-aging to immune-paralysis: a slippery slope during aging for immune-adaptation. Biogerontology 17, 147-157.

Fulop T., Larbi A., Dupuis G., Le Page A., Frost E. H., COHEN A. A., WiTKOWSKI J. M., FRANCESCHI C., 2017. Immunosenescence and inflamm-aging as two sides of the same coin: friends or foes? Front. Immunol. 8, doi: 10.3389/fimmu.2017.01960.

FulOP T., WiTKOWSKI J. M., BOURGADE K., KHALIL A., ZeriF E., LARBI A., HiRokaWA K., PAWelec G., Bocti C., Lacombe G., Dupuis G., Frost E. H., 2018a. Can an infection hypothesis explain the beta amyloid hypothesis of Alzheimer's disease? Front. Aging Neurosci. 10, doi: 10.3389/fnagi.2018.00224.

FULOP T., WiTKOWSKI J. M., OLIVIERI F., LARBI A., $2018 \mathrm{~b}$. The integration of inflammaging in age-related diseases. Semin. Immunol. 40, 17-35.

FUlOP T., LARBI A., WiTKOWSKI J. M., 2019a. Human inflammaging. Gerontology 65, 495-504.

FulOP T., WITKOWSKI J. M., LARBI A., KHALIL A., HERBEIN G., FROST E. H., 2019b. Does HIV infection contribute to increased beta-amyloid synthesis and plaque formation leading to neurodegeneration and Alzheimer's disease? J. Neurovirol. 25, 634-647.

Fulop T., LaRBi A., Hirokawa K., COHEN A. A., WITKOWSKI J. M., 2020a. Immunosenescence is both functional/adaptive and dysfunctional/ maladaptive. Semin. Immunopathol. 42, 521536. 
Fulop T., Munawara U., LARBI A., DEsRoches M., Rodrigues S., CATANZARO M., GUIDOLIN A., Khalil A., Bernier F., Barron A. E., HiROKAWA K., BEAUREGARD P. B., DUMOULIN D., Bellenger J. P., Witkowski J. M., Frost E., 2020b. Targeting infectious agents as a therapeutic strategy in Alzheimer's disease. CNS Drugs 34, 673-695.

Fulop T., TRIPATHI S., RodRigues S., DESROCHES M., Bunt T., EISER A., BERNIER F., BEAUREGARD P. B., BARRON A. E., KHALIL A., PlOtKA A., Hirokawa K., Larbi A., Bocti C., LaURENT B., Frost E. H., WiTKOWsKI J. M., 2021. Targeting impaired antimicrobial immunity in the brain for the treatment of Alzheimer's disease. Neuropsychiatr. Dis. Treat. 17, 1311-1339.

Hu B., HUANG S., YIN L., 2021. The cytokine storm and COVID-19. J. Med. Virol. 93, 250256.

JesuTHASAN A., MASsey F., MANJi H., Zandi M. S., WIETHOFF S., 2021. Emerging potential mechanisms and predispositions to the neurological manifestations of COVID-19. J. Neurol. Sci. 428, doi: 10.1016/j.jns.2021.117608.

JOZWIK A., LANDOWSKI J., BIDZAN L., FULOP T., BRYL E., WITKOWSKI J. M., 2012. Beta-amyloid peptides enhance the proliferative response of activated CD4CD28 lymphocytes from Alzheimer disease patients and from healthy elderly. PLoS One 7, e33276.

KerslaKe R., Hall M., Randeva H. S., SPANDIDOS D. A., ChATHA K., KYROU I., KARTERIS E., 2020. Coexpression of peripheral olfactory receptors with SARSCoV2 infection mediators: Potential implications beyond loss of smell as a COVID19 symptom. Int. J. Mol. Med. 46, 949-956.

Koetz K., Bryl E., SPICKSchen K., O'Fallon W. M., GoRONZY J. J., WeyAND C. M., 2000. T cell homeostasis in patients with rheumatoid arthritis. Proc. Natl. Acad. Sci. USA 97, 92039208.

le Page A., Dupuis G., Frost E. H., Larbi A., PAWELEC G., WiTKOWSKI J. M., FUlOP T., 2018a. Role of the peripheral innate immune system in the development of Alzheimer's disease. Exp. Gerontol. 107, 59-66.

LE PAge A., Dupuis G., LARBi A., WitKowski J. M., FUlOP T., 2018b. Signal transduction changes in CD4(+) and CD8(+) T cell subpopulations with aging. Exp. Gerontol. 105, 128139.

LEI Y., Zhang J., Schiavon C. R., HE M., ChEN L., Shen H., ZHANG Y., YIN Q., CHO Y., ANDRADE L., SHADEL G. S., HEPOKOSKI M., LEI T., WANG H., ZHANG J., YUAN J. X., MALHOTRA A., MANOR U., WANG S., YUAN Z. Y., SHYY J. Y., 2021. SARS-CoV-2 spike protein impairs endothelial function via downregulation of $A C E$ 2. Circ. Res. 128, 1323-1326.

Li H., LiU L., Zhang D., Xu J., Dai H., TANG N., SU X., CAO B., 2020. SARS-CoV-2 and viral sepsis: observations and hypotheses. Lancet $395,1517-1520$.

Lopez-Otin C., Blasco M. A., Partridge L., SerRANO M., KROEMER G., 2013. The hallmarks of aging. Cell 153, 1194-1217.

Munawara U., Catanzaro M., Xu W., TAN C., HiRoKawa K., Bosco N., Dumoulin D., KHAlil A., Larbi A., Levesque S., Ramassamy C., BARRon A. E., CunNane S., BeAurEgard P. B., Bellenger J. P., Rodrigues S., DesRoChes M., Witkowski J. M., Laurent B., Frost
E. H., FULOP T., 2021. Hyperactivation of monocytes and macrophages in MCI patients contributes to the progression of Alzheimer's disease. Immun. Ageing 18, doi: 10.1186/ s12979-021-00236-x.

NaYlor K., Li G., Vallejo A. N., Lee W. W., KoETZ K., BRYL E., WITKOWSKI J., FULBRIGHT J. WEYAND C. M., GORONZY J. J., 2005. The influence of age on $T$ cell generation and TCR diversity. J. Immunol. 174, 7446-7452.

Pum A., ENNEmoser M., ADAGE T., Kungl A. J., 2021. Cytokines and chemokines in SARS -CoV-2 infections-therapeutic strategies targeting cytokine storm. Biomolecules, 11, doi: $10.3390 /$ biom 11010091 .

Ragan I., HARTSON L., PIDCOKE H., BOWEN R., GOODRICH R., 2020. Pathogen reduction of SARS-CoV-2 virus in plasma and whole blood using riboflavin and UV light. PLoS One 15, e0233947.

SEllegounder D., ZAFARI P., RAJABINEJAD M., TAGHADOSI M., KAPAHI P., 2021. Advanced glycation end products (AGEs) and its receptor RAGE, modulate age-dependent COVID-19 morbidity and mortality. A review and hypothesis. Int. Immunopharmacol. 98, doi: 10.1016/j.intimp.2021.107806.

STARK H., FICHTNER M., KONIG R., LORKOWSKI S., SCHUSTER S., 2015. Causes of upregulation of glycolysis in lymphocytes upon stimulation. A comparison with other cell types. Biochimie $118,185-194$.

TAHAGHOGHI-HAJGHORBANI S., ZAFARI P., MASOUMI E., RAJABINEJAD M., JAFARI-SHAKIB R., HASANI B., RAFIEI A., 2020. The role of dysregulated immune responses in COVID-19 pathogenesis. Virus Res. 290, doi: 10.1016/j.virusres.2020.198197.

Tercan H., Riksen N. P., Joosten L. A. B., Netea M. G., BEKKERING S., 2021. Trained immunity: long-term adaptation in innate immune responses. Arterioscler. Thromb. Vasc. Biol. 41, 5561.

Torices S., CABrera R., Stangis M., NARANJo O., FatTakHov N., Teglas T., Adesse D., ToBOREK M., 2021. Expression of SARS-CoV-2-related receptors in cells of the neurovascular unit: implications for HIV-1 infection. J. Neuroinflammation 18, doi: 10.1186/s12974-02102210-2.

V'Kovski P., KRATZel A., Steiner S., Stalder H., THIEL V., 2021. Coronavirus biology and replication: implications for SARS-CoV-2. Nat. Rev. Microbiol. 19, 155-170.

WitKOWSKI J. M., BRYL E., FulOP T., 2019. Should we try to alleviate immunosenescence and inflammaging - Why, how and to what extent? Curr. Pharm. Des. 25, 4154-4162.

Wu T., Kang S., Peng W., ZuO C., Zhu Y., Pan L., FU K., You Y., YANG X., LUO X., JiANG L., DENG M., 2021. Original hosts, clinical features, transmission routes, and vaccine development for coronavirus disease (COVID-19). Front. Med. 8, doi: 10.3389/ fmed.2021.702066.

YANG K., CHI H., 2012. mTOR and metabolic pathways in $T$ cell quiescence and functional activation. Semin. Immunol. 24, 421-428.

YoNG S. J., 2021. Long COVID or post-COVID-19 syndrome: putative pathophysiology, risk factors, and treatments. Infect. Dis. 53, 737-754. 
KOSMOS Vol. 70, 3, 407-417, 2021

\author{
JACEK M. WITKOWSKI ${ }^{1}$, EWA BRYL ${ }^{2}$
}

${ }^{1}$ Chair and Department of Physiopathology, ${ }^{2}$ Division of Pathology and Experimental Rheumatology, Medical University of Gdansk, 7 Dębinki Str.,80-211 Gdańsk,E-mail: jacek.witkowski@gumed.edu.pl

\title{
MECHANISMS OF COVID-19, THE IMMUNE SYSTEM AND ITS AGING
}

\section{Summary}

Epidemiological studies concerning the new coronavirus disease called COVID-19 show that elderly and old people are more susceptible to symptomatic, severe course of the disease, and also to death as its consequence. These age groups frequently suffer from associated, aging-related, chronic inflammatory diseases, in the case of COVID-19 described as co-morbidities. This paper describes the mechanisms of infection by SARS-CoV-2 virus and the development of acute COVID-19 and of its chronic form called long COVID, as well as the participation of various components of the immune system in the development and course of this disease in the context of changing properties (aging) of both the innate and adaptive immunity in the elderly. In particular, the role of two key phenomena occurring in the aging immune system and precipitating or at least facilitating the aging-related diseases including COVID-19, namely the immunosenescence and inflammaging, is discussed.

Key words: adaptive immunity, COVID-19, cytokine storm, immunosenescence, inflammaging, innate immunity, immune system aging 